JIPS, Vol. 1 No. 1

Halaman: 37 - 52

Desember 2020
Jurnal Inovasi Pembelajaran di Sekolah

DOI: https://doi.org/10.51874/jips.v1i01.6

ISSN 2774-9363 (Cetak)

ISSN 2774-9746 (Online)

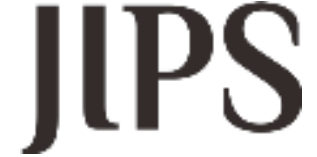

Jurnal Inovasi Pembelajaran di Sekolah

\title{
Upaya Meningkatkan Hasil Belajar Pendidikan Pancasila dan Kewarganegaraan Melalui Model Pembelajaran Kontekstual Pada Siswa Kelas XI TKRO SMK Negeri 3 Semarang Tahun Pelajaran 2018-2019
}

\author{
Sutrisno ${ }^{1}$ \\ ${ }^{1}$ SMK Negeri 3 Semarang
}

\begin{abstract}
Abstrak
Penelitian tindakan kelas ini bertujuan untuk mengetahui apakah penggunaan model pembelajaran kontekstual dapat meningkatkan hasil belajar PKn pada siswa kelas XI TKRO SMK Negeri 3 Semarang Tahun Pelajaran 2018/2019. Penelitian ini dilaksanakan di SMK Negeri 3 Semarang. Jenis penelitian ini adalah kualitatif dengan menggunakan pendekatan penelitian tindakan kelas. Data utama diperoleh dari informan seperti kepala sekolah, dan guru. Metode pengumpulan data dengan observasi, wawancara mendalam, dan metode dokumentasi. Hasil penelitian menunjukkan bahwa (1) Adanya peningkatan hasil belajar siswa yang ditunjuukkan dengan adanya peningkatan nilai rata-rata dari data awal 72,07 meningkat menjadi 76,38 pada siklus I dan meningkat kembali menjadi 80,34 pada siklus II. Dangan ketuntasan dari 41,38\% meningkat menjadi 62,86\% pada siklus I dan mencapai $93,10 \%$ pada siklus II; (2) Adanya peningkatan aktivitas belajar siswa dari data awal 41,38\% siswa yang aktif dalam pembelajaran meningkat menjadi $63,79 \%$ pada siklus I dan meningkat kembali pada siklus II menjadi $88,79 \%$.
\end{abstract}

Kata kunci: model kontekstual, hasil belajar, aktivitas, PPKn

\begin{abstract}
This class action research aims to find out if the use of contextual learning models can improve PKn learning outcomes in grade XI students of TKRO SMK Negeri 3 Semarang Year 2018/2019. This research was conducted at SMK Negeri 3 Semarang. This type of research is qualitative by using a class action research approach. The main data is obtained from informants such as principals, and teachers. Data collection methods with observations, in-depth interviews, and documentation methods. The results showed that (1) The increase in student learning outcomes was achieved by an increase in average grades from the initial data of 72.07 increased to 76.38 in the first cycle and increased again to 80.34 in the second cycle. The completeness of $41.38 \%$ increased to $62.86 \%$ in the first cycle and reached $93.10 \%$ in the second cycle; (2) The increase in student learning activities from the initial data of $41.38 \%$ of students active in learning increased to $63.79 \%$ in the first cycle and increased again in the second cycle to $88.79 \%$.
\end{abstract}

Keywords: contextual model, learning outcomes, activities, PPKn 


\section{PENDAHULUAN}

Sekolah memiliki peranan dan tanggung jawab yang sangat penting dalam mempersiapkan warga negara yang memiliki komitmen kuat dan konsisten untuk mempertahankan Negara Kesatuan Republik Indonesia. Upaya yang dapat dilakukan adalah menyelenggarakan program pendidikan yang memberikan berbagai kemampuan sebagai seorang warga negara melalui berbagai mata pelajaran termasuk salah satunya Pendidikan Pancasila dan Kewarganegaraan.

Kemampuan dasar, materi pokok, dan indikator pencapaian hasil belajar yang dicantumkan dalam Standar Nasional merupakan bahan minimal yang harus dikuasai siswa. Oleh karena itu, daerah, sekolah atau guru dapat mengembangkan, menggabungkan, atau menyesuaikan bahan yang disajikan dengan situasi dan kondisi setempat Realitanya hasil belajar siswa dalam materi Pendidikan Pancasila dan Kewarganegaraan belum menunjukkan hasil yang diinginkan.

Kondisi rendahnya hasil belajar siswa dalam materi hakekat negara tercermin juga dalam hasil belajar siswa pada siswa kelas XI TKRO. Hal itu dapat diketahui dari rata-rata nilai harian siswa. Pada tiga kali ulangan harian yang diadakan guru dengan kompetensi dasar hakekat negara menunjukkan rata-rata kurang dari nilai 70 . Dari ulangan harian yang pernah dilakukan, $\pm 60 \%$ siswa mendapatkan nilai dibawah 75,00. Angka-angka tersebut dapat diartikan, bahwa pemahaman siswa terhadap mata pelajaran Pendidikan Pancasila dan Kewarganegaraan tersebut relatif masih rendah. Dengan kata lain, pemahaman siswa SMK Negeri 3 Semarang terhadap mata pelajaran Pendidikan Pancasila dan Kewarganegaraan yang diajarkan mencapai baru tercapai sekitar 40 persen.

Secara tidak disadari, karena rutinitas tugasnya mengakibatkan guru tidak begitu menghiraukan/peduli apakah siswanya telah atau belum memperoleh pengalaman belajar yang bermakna. Sejauh mana siswa telah mengerti (understanding) dan tidak hanya sekedar tahu (knowing), tentang konsep Pendidikan Pancasila dan Kewarganegaraan yang sudah disampaikan dalam proses pembelajaran? Rutinitas yang dilakukan para guru tersebut meliputi penggunaan metode pembelajaran yang cenderung monoton yaitu kapur dan tutur (chalk-and-talk), kurangnya pelaksanaan evaluasi selama proses kegiatan belajar mengajar (KBM) berlangsung, serta kecenderungan penggunaan soal-soal bentuk pilihan ganda murni pada waktu ulangan harian maupun ulangan sumatif tiap akhir semester.

Sebelum penelitian dilakukan guru memang belum mengoptimalkan metode kontekstual. Guru baru sebatas memanfaatkan metode ceramah serta penugasan (PR) kepada siswa. Kalaupun ada penugasan, siswa hanya di beri pekerjaan rumah yang dinilai secara individual oleh guru tanpa didiskusikan di kelas. Secara operasional, guru menjelaskan materi kepada siswa kemudian memberikan contoh-contoh di papan tulis. Setelah selesai menerangkan materi, guru menyuruh siswa untuk mengerjakan soal.

Kenyataan hasil belajar siswa dalam materi hakekat negara yang rendah tersebut perlu diperbaiki sebab Pendidikan Pancasila dan Kewarganegaraan termasuk mata pelajaran inti dengan nilai minimum ketuntasan belajar 70. Disamping itu, dalam Kurikulum Tingkat Satuan Pendidikan Sekolah Menengah Atas juga dinyatakan bahwa salah satu tujuan pembelajaran Pendidikan Pancasila dan Kewarganegaraan adalah agar siswa menaruh perhatian terhadap isu-isu dan masalah-masalah sosial, serta mampu membuat analisis yang kritis, selanjutnya mampu mengambil tindakan yang tepat.

Salah satu upaya yang dilakukan guru untuk mengatasi permasalahn dalam pembelajaran PPPKn adalah dengan menggunakan pendekatan kontekstual. Pendekatan kontektual (contextual teaching learning) merupakan konsep belajar yang membantu guru mengaitkan antara materi yang diajarkannya dengan situasi dunia nyata siswa dan mendorong siswa membuat hubungan antara pengetahuan yang memilikinya dengan penerapannya dalam kehidupan mereka sebagai anggota keluarga dan masyarakat. Dengan konsep itu, hasil pembelajaran diharapkan lebih bermakna bagi siswa.

Dalam pemeblajaran kontekstual, proses pembelajaran berlangsung alamiah dalam bentuk kegiatan siswa bekerja dan mengalami, bukan transfer pengetahuan dari guru ke siswa. Dalam 
konteks itu siswa perlu mengerti apa makna belajar, apa manfaatnya, dan bagaimana mencapainya. Mereka sadar bahwa yang mereka pelajari berguna bagi hidupnya nanti. Mereka mempelajari apa yang bermanfaat bagi dirinya dan berupaya menggapainya. Dalam upaya itu memerlukan guru pengarah dan pembimbing.

Dalam kelas kontekstual, tugas guru adalah membantu siswa mencapai tujuannya, maksudnya guru lebih banyak berurusan dengan strategi dari pada memberi informasi. Tugas guru engelola kelas sebagai sebuah tim yang berkerja sama untuk menemukan sesuatu yang baru bagi anggota kelas (siswa). Kontektual hanya sebuah strategi pembelajaran, yang bertujuan agar pembelajaran berjalan lebih produktif dan bermakna. Pendekatan kontektual dapat dijalankan tanpa harus mengubah kurikulum dan tatanan yang ada.

Pengajaran dengan menggunakan pendekatan kontrekstual akan memberikan pengalaman pada siswa untuk melihat dan memahami bagaimana membelajaran PPKn dalam kehidupan seharihari. Untuk itu, agar dapat mencapai tujuan pembelajaran PPKn di sekolah sadar sangat tergantung skenario pembelajaran yang disusun dan dilaksanakan oleh guru, dalam proses pembelajaran guru hendaknya berupaya agar memberikan kegiatan yang mengarah pada kegiatan berbuat atau melakukan tindakan nyata atau kongkret. Dengan penggunaan pendekatan CTL dengan metode inquiri diharapkan dapat meningkatkan motivasi belajar siswa.

Melalui tindakan yang akan dilakukan guru, hasil belajar siswa dalam mata pelajaran Pendidikan Pancasila dan Kewarganegaraan akan meningkat. Nilai rata-rata ulangan harian yang diharapkan setelah penelitian adalah 75 atau mencapai nilai batas ketuntasan belajar Pendidikan Pancasila dan Kewarganegaraan. Guna meningkatkan hasil belajar siswa dalam materi hakekat negara siswa, guru perlu melakukan tindakan kelas yakni dengan memperbaiki proses pembelajaran dengan memodifikasi pola pembelajaran yang selama ini hanya monoton pembelajaran kelas dengan ceramah menjadi pembelajaran mandiri atas dasar inisiatif siswa.

Berdasarkan uraian di atas nampak adanya kesenjangan antara kondisi nyata dengan harapan. Kesenjangan pokok dari subyek yakni pada kondisi awal hasil belajar siswa dalam materi hakekat negara yang rendah sedangkan kondisi akhir yang diharapkan hasil belajar siswa dalam materi hakekat negara meningkat. Kesenjangan pokok dari peneliti yakni pada kondisi awal peneliti masih menyampaikan materi menggunakan model pembelajaran konvensional sedangkan kondisi akhir peneliti menggunakan metode kontekstual. Jadi, upaya untuk memecahkan masalah dari kesenjangan yang terjadi adalah guru perlu menerapkan metode kontekstual. Kegiatan kontekstual dilakukan secara mandiri, artinya siswa sesuai prosedur kerja diberi kebebasan untuk berkreasi sendiri dan tidak berada di bawah dikte guru.

Dari uraian di atas muncul kerangka pemikiran bahwa rendahnya nilai mata pelajaran Pendidikan Pancasila dan Kewarganegaraan dikarenakan siswa kurang memahami konsep hakekat negara yang selama ini hanya diajarkan guru melalui metode ceramah. Sa ara untuk mengatasi hal tersebut adalah pelaksanaan kegiatan tindak lanjut berupa in dengan menerapkan metode kontekstual. Hal itu dimaksudkan agar siswa dapat mudan memahami dan menerima materi yang disampaikan guru yang secara tidak langsung memberi penekanan agar siswa memperhatikan penjelasan guru dan pada akhirnya siswa akan lebih memahami konsep hakekat Negara yang dipelajarinya. Dengan demikian adanya pemahaman konsep tersebut maka akan dapat membantu meningkatkan pemahaman siswa dan akhirnya akan dapat mengatasi rendahnya hasil belajar siswa.

\section{METODE}

Subjek penelitian ini adalah siswa kelas XI TKRO SMK Negeri 3 Semarang tahun pelajaran 2018/2019 yang berjumlah 29 siswa. Penelitian ini dilaksanakan selama tiga bulan dengan diawali kegiatan pra tindakan, yaitu dari bulan April sampai dengan Mei 2019.

Penelitian ini dilakukan dengan menggunakan desain PTK yang menerapkan siklus. Siklus tersebut terdiri atas 4 kegiatan yaitu perencanaan tindakan, pelaksanaan tindakan, observasi tindakan, dan refleksi tindakan (Anonim, 1999: 93). Untuk mengetahui tingkat pemahaman konsep materi dan perubahannya, peserta didik diberi tes pada setiap siklus. 
Dengan uraian tersebut di atas, penelitian dirancang melalui 2 siklus tindakan sebagai berikut.

\section{Siklus I}

a. Perencanaan Tindakan Siklus I

1) Mempersiapkan materi pembelajaran

2) Mempersiapkan sumber belajar yang diperlukan

3) Mempersiapkan lembar kerja siswa

4) Mempersiapkan kelas dalam setting pembelajaran kontekstual

5) Membuat lembar observasi tentang aktivitas siwa selama proses belajar mengajar

b. Pelaksanaan Tindakan Siklus I

1) Pertemuan 1

a) Guru melakukan apersepsi dan memberikan motivasi kepada siswa

b) Guru menjelaskan materi dan memberikan contoh-contoh soal

c) Siswa mendengarkan penjelasan guru dan mencatat

d) Siswa berlatih menyelesaikan soal-soal seperti dicontohkan oleh guru

e) Siswa mendiskusikan materi

f) Siswa membuat rangkuman

g) Guru memberikan tugas pekerjaan rumah

2) Pertemuan 2
a) Siswa dibagi menjadi beberapa kelompok
b) Dalam kelompoknya siswa melakukan diskusi
c) Siswa menganalisis hasil diskusi
d) Beberapa kelompok mempresentasikan hasil diskusinya dan kelompok lain menanggapinya
e) Siswa bersama guru menyimpulkan materi
f) Siswa mengerjakan soal evaluasi

c. Observasi Siklus I

1) Guru mengamati pelaksanaan proses belajar mengajar agar berjalan seoptimal mungkin

2) Guru mengamati dan mencatat tindakan aktifitas siswa

d. Refleksi Siklus I

1) Mengevaluasi hasil pemantauan dan mengolah data hasil evaluasi serta menentukan keberhasilan pencapaian tujuan tindakan.

2) Mencatat perkembangan kemampuan siswa.

3) Mengadakan refleksi I dengan meneliti kembali tindakan yang telah dilakukan.

4) Memberi penguatan dan motivasi kepada siswa agar belajar lebih giat.

\section{Siklus II}

a. Perencanaan tindakan siklus II

1) Mempersiapkan materi pembelajaran

2) Mempersiapkan sumber belajar yang diperlukan

3) Mempersiapkan lembar kerja siswa

4) Mempersiapkan kelas dalam setting pembelajaran kontekstual dengan bantuan media pembelajaran

5) Membuat lembar observasi tentang aktivitas siwa selama proses belajar mengajar

b. Pelaksanaan tindakan siklus II

1) Pertemuan 1

a) Guru memberikan motivasi dan melakukan apersepsi

b) Siswa dibagi menjadi enam kelompok

c) Guru memberikan penjelasan tentang penggunaan LCD untuk menyampaian materi pembelajaran

d) Guru memberikan penjelasan tentang materi pembelajaran

e) Siswa melakukan pengamatan dan mendiskusikan materi pembelajaran 
f) Siswa membuat kesimpulan

g) Siswa diberikan tugas rumah

2) Pertemuan 2

a) Siswa melaksanakan diskusi dengan kelompok yang sama

b) Siswa menganalisis hasil diskusi

c) Beberapa kelompok mempresentasikan hasil diskusinya dan kelompok lain menanggapinya

d) Siswa bersama guru menyimpulkan materi

e) Siswa mengerjakan soal evaluasi

c. Observasi siklus II

1) Mengamati pelaksanaan proses belajar mengajar agar berjalan seoptimal mungkin

2) Mengamati dan mencatat tindakan aktifitas siswa

d. Refleksi siklus II

1) Mengevaluasi hasil pemantauan dan mengolah data hasil evaluasi serta menentukan keberhasilan pencapaian tujuan tindakan.

2) Mencatat perkembangan kemampuan siswa.

3) Mengadakan refleksi I dengan meneliti kembali tindakan yang telah dilakukan.

4) Memberi penguatan dan motivasi kepada siswa agar belajar lebih giat.

\section{A. Hasil Penelitian}

\section{HASIL DAN PEMBAHASAN}

\section{Deskripsi Data Awal}

Pembelajaran PPKn lebih menekankan pada aspek kurikulum atau rencana dengan mengutamakan cara mengembangkan tingkah laku social siswa untuk mencapai suatu hasil pendidikan berupa warga Negara yang baik. Jadi jelas bahwa penbahasan tentang Pendidikan Pancasila dan Kewarganegaraan dapat dinyatakan sebagai program pendidikan yang diciptakan dan dikembangkan oleh setiap bangsa-bangsa (dengan nama berbeda-beda) untuk menjamin terpeliharanya masyarakat dan bangsa dalam rangka mempertahankan dan mengembangkan kehidupan bangsa itu sendiri).

Untuk mengetahui hasil belajar siswa pada mata pelajaran PPKn, peneliti melakukan evaluasi. Evaluasi dirancang sebagai tindakan observasi lapangan untuk mengetahui situasi pembelajaran sebelumnya yaitu pembelajaran dengan metode ceramah dan tanya jawab. Pembelajaran dengan menggunakan metode ceramah dan tanya jawab dilaksanakan tanpa menggunakan media pembelajaran sebagai alat bantu. Dimana guru menjalaskan bagaimana cara pembelajaran yang dimengerti siswa.

Pada saat pembelajaran berlangsung, siswa mendengarkan sedangkan guru menerangkan dan berceramah mengenai materi menampilkan sikap positif terhadap Pancasila sebagai ideologi terbuka di depan kelas. Dalam kondisi seperti itu, siswa terlihat jenuh, bosan dan kurang bergairah. Sedangkan ada beberapa siswa yang mengalihkan perhatiannya dengan bermain sendiri, menulis, bahkan berbicara dengan temannya pada saat guru menerangkan. Setelah guru selesai menerangkan, kemudian memberikan kesempatan kepada siswa untuk bertanya apa yang belum dimengerti dari keterangan tersebut. Pada sesi tersebut hanya satu dua orang yang bertanya.

Untuk memberikan umpan balik, guru mencoba melempar pertanyaan kepada siswa yang lain sebelum dijawab oleh guru, Namun siswa hanya diam tidak begitu memperhatikan hanya ada satu dua orang yang berusaha menjawab. Bahkan di tempat duduk yang lain ada siswa yang tengah asyik bermain sendiri dengan temannya, sehingga kelas terkesan tidak hidup karena tidak ada interaksi edukatif antara guru dan siswa.

Pada akhir pembelajaran tidak dilaksanakan evaluasi dan refleksi. Selanjutnya guru menulis soal pre test dan siswa menulis soal tersebut dan dikerjakan. Hal ini untuk mengetahui efektivitas dari pembelajaran dengan metode ceramah dan Tanya jawab. Dalam mengerjakan 
soal pre test siswa tampak kurang bersemangat, dan kurang bergairah. Kemudian pembelajaran ditutup dengan salam.

Melalui kegiatan pembelajaran ini, diharapkan dapat diketahui hasil belajar siswa dalam pembelajaran PPKn dan juga aktivitas belajar siswa dalam kegiatan pembelajaran. Berdasarkan evaluasi yang dilakukan, berikut disajikan hasil belajar siswa dalam pembelajaran PPKn.

Tabel 4.1 Rekapitulasi Data Awal Hasil Belajar PPKn Siswa Kelas XI

SMK Negeri 3 Semarang

\begin{tabular}{|c|c|c|c|}
\hline No & Nama Siswa & Nilai & Keterangan \\
\hline 1 & Abdul Latif Agus Solikhin & 70 & Tidak Tuntas \\
\hline 2 & Adam Fajar Prasetya & 75 & Tuntas \\
\hline 3 & Adhika Muhammad Rizki & 70 & Tidak Tuntas \\
\hline 4 & Agil Lintang Tristiawan & 65 & Tidak Tuntas \\
\hline 5 & Agung Dwi Laksono & 80 & Tuntas \\
\hline 6 & Ahmad Arjuna Kurniawan & 65 & Tidak Tuntas \\
\hline 7 & Andre Pramuji Utama & 75 & Tuntas \\
\hline 8 & Aprialdo Budi Hendriawan & 65 & Tidak Tuntas \\
\hline 9 & Bachtiar Hanif & 70 & Tidak Tuntas \\
\hline 10 & Bagas Pramudita & 75 & Tuntas \\
\hline 11 & Djamaludin Akbar & 70 & Tidak Tuntas \\
\hline 12 & Edwin Mahendra & 75 & Tuntas \\
\hline 13 & Galang Awal Yanuar & 70 & Tidak Tuntas \\
\hline 14 & Harry Setiawan & 85 & Tuntas \\
\hline 15 & Heri & 70 & Tidak Tuntas \\
\hline 16 & Insan $\mathrm{Al}$ Faridzi & 75 & Tuntas \\
\hline 17 & Keavin Putra Purnama & 65 & Tidak Tuntas \\
\hline 18 & M. Hafis Arida Saputro & 80 & Tuntas \\
\hline 19 & Mohammad Dafa Rizqi Fernanda & 70 & Tidak Tuntas \\
\hline 20 & Muhammad Aldi Dwi Kresna & 70 & Tidak Tuntas \\
\hline 21 & Muhammad Nuqoib & 80 & Tuntas \\
\hline 22 & Rafli Azril Kautsar & 70 & Tidak Tuntas \\
\hline 23 & Ramadhan Alfarizi & 65 & Tidak Tuntas \\
\hline 24 & Ridho Kusdiantoro & 75 & Tuntas \\
\hline 25 & Roy Evan Adnadya & 70 & Tidak Tuntas \\
\hline 26 & Tian Fajar Nugraha & 65 & Tidak Tuntas \\
\hline 27 & Vitho Perdana & 75 & Tuntas \\
\hline 28 & Yoga Aprilian & 70 & Tidak Tuntas \\
\hline 29 & Yusuf Lutfi Anabil & 80 & Tuntas \\
\hline \multirow{3}{*}{\multicolumn{2}{|c|}{$\begin{array}{l}\text { Rata-rata } \\
\text { Nilai Tertinggi } \\
\text { Nilai Terendah }\end{array}$}} & 72,07 & \\
\hline & & 85 & \\
\hline & & 65 & \\
\hline
\end{tabular}

Berdasarkan tabel di atas dapat diinformasikan bahwa nilai rata-rata data awal siswa kelas XI pada mata pelajaran PPKn adalah 72,07. Sementara itu, secara klasikal, jumlah siswa yang hasil belajarnya tuntas mencapai $41,38 \%$ atau ada 12 siswa yang nilainya tuntas. Sisanya sebesar 58,62\% siswa tidak tuntas hasil belajarnya atau ada 17 siswa. hal tersebut tentunya menunjukkan bahwa hasil belajar siswa masih rendah 
Hal yang hampir sama juga trelihat dari aktivitas siswa selama pembelajaran. Hal tersebut dapat dilihat pada tabel berikut ini.

Tabel 4.2 Rekapitulasi Data Awal Hasil Observasi Aktivitas Siswa kelas XI Dalam Pembelajaran PPKn

\begin{tabular}{|c|l|c|c|}
\hline \multirow{2}{*}{ No } & \multicolumn{1}{|c|}{ Aspek Penilaian } & \multicolumn{2}{c|}{ Jumlah Siswa } \\
\cline { 3 - 4 } & \multicolumn{1}{|c|}{ Aktif } & $\begin{array}{c}\text { Tidak } \\
\text { Aktif }\end{array}$ \\
\hline 1 & Siswa Aktif Bertanya dan Menjawab Pertanyaan & 10 & 19 \\
\hline 2 & Siswa Aktif Bekerjasama & 12 & 17 \\
\hline 3 & Siswa Aktif Melaksanakan Tugas & 14 & 15 \\
\hline & $\begin{array}{l}\text { Siswa aktif menyampaikan pendapat mengenai } \\
\text { pokok bahasan }\end{array}$ & 11 & 18 \\
\hline \multicolumn{2}{|l|}{ Jumlah } & 47 & 69 \\
\hline \multicolumn{2}{|l|}{ Prosentase } & $40,52 \%$ & $59,48 \%$ \\
\hline
\end{tabular}

Tabel di atas menunjukkan bahwa prosentase siswa yang aktif dalam pembelajaran mencapai $40,52 \%$, sedangkan siswa yang tidak aktif dalam pembelajaran mencapai 59,48\%. Hasil tersebut menunjukkan bahwa keaktifan siswa dalam pembelajaran PPKn masih sangat kurang. Pembelajaran dengan menggunakan metode ceramah dan Tanya jawab tidak cocok untuk diterapkan dalam pembelajaran PPKn pada materi menampilkan sikap positif terhadap Pancasila sebagai ideologi terbuka.

Dari hasil pre test dapat diambil kesimpulan bahwa strategi konvensional dengan metode ceramah dan Tanya jawab tidak cocok diterapkan pada pembelajaran PPKn. Strategi ini masih bersifat statis, pasif, doktriner dan tidak menarik bagi siswa, dan kurang dikaitkan dengan kebutuhan siswa dalam kehidupan seharí-hari. Pembelajaran yang demikian kurang mendorong siswa untuk aktif dan menghambat kreativitas siswa.

\section{Siklus I}

\section{a. Perencanaan}

Pada perencanaan siklus I, peneliti menetapkan penerapan inkuiri sebagai pendekatan yang akan diterapkan. Selanjutnya peneliti melakukan tahap-tahap persiapan untuk penerapan pendekatan inkuiri. Adapun beberapa tahap persiapan tersebut sebagai berikut:

1) Mempersiapkan materi pembelajaran

2) Mempersiapkan sumber belajar yang diperlukan

3) Mempersiapkan lembar kerja siswa

4) Mempersiapkan kelas dalam setting pembelajaran kontekstual

5) Membuat lembar observasi tentang aktivitas siwa selama proses belajar mengajar

b. Pelaksanaan Tindakan Siklus I

Pada siklus I ini, tindakan dilaksanakan dua kali pertemuan. Berikut uraikan lengkapnya.

1) Pertemuan 1

a) Guru melakukan apersepsi dan memberikan motivasi kepada siswa

b) Guru menjelaskan materi dan memberikan contoh-contoh soal

c) Siswa mendengarkan penjelasan guru dan mencatat

d) Siswa berlatih menyelesaikan soal-soal

e) Siswa mendiskusikan materi

f) Siswa membuat rangkuman

g) Guru memberikan tugas pekerjaan rumah 
2) Pertemuan 2

a) Siswa dibagi menjadi beberapa kelompok

b) Dalam kelompoknya siswa melakukan diskusi

c) Siswa menganalisis hasil diskusi

d) Beberapa kelompok mempresentasikan hasil diskusinya dan kelompok lain menanggapinya

e) Siswa bersama guru menyimpulkan materi

f) Siswa mengerjakan soal evaluasi

Dalam pelaksanaan tindakan siklus I, dilakukan evaluasi pembelajaran yang dilaksanakan pada pertemuan kedua. Berdasarkan evaluasi yang dilakukan diperoleh data mengenai hasil belajar siswa di bawah ini.

Tabel. 4.3 Rekapitulasi Hasil Belajar PPKn Siswa Kelas X SMK Negeri 3 Semarang Siklus I

\begin{tabular}{|c|c|c|c|}
\hline No & Nama Siswa & Nilai & Keterangan \\
\hline 1 & Abdul Latif Agus Solikhin & 75 & Tuntas \\
\hline 2 & Adam Fajar Prasetya & 85 & Tuntas \\
\hline 3 & Adhika Muhammad Rizki & 75 & Tuntas \\
\hline 4 & Agil Lintang Tristiawan & 65 & Tidak Tuntas \\
\hline 5 & Agung Dwi Laksono & 90 & Tuntas \\
\hline 6 & Ahmad Arjuna Kurniawan & 70 & Tidak Tuntas \\
\hline 7 & Andre Pramuji Utama & 85 & Tuntas \\
\hline 8 & Aprialdo Budi Hendriawan & 70 & Tidak Tuntas \\
\hline 9 & Bachtiar Hanif & 70 & Tidak Tuntas \\
\hline 10 & Bagas Pramudita & 80 & Tuntas \\
\hline 11 & Djamaludin Akbar & 70 & Tidak Tuntas \\
\hline 12 & Edwin Mahendra & 80 & Tuntas \\
\hline 13 & Galang Awal Yanuar & 75 & Tuntas \\
\hline 14 & Harry Setiawan & 90 & Tuntas \\
\hline 15 & Heri & 75 & Tuntas \\
\hline 16 & Insan Al Faridzi & 80 & Tuntas \\
\hline 17 & Keavin Putra Purnama & 70 & Tidak Tuntas \\
\hline 18 & M. Hafis Arida Saputro & 85 & Tuntas \\
\hline 19 & $\begin{array}{l}\text { Mohammad Dafa Rizqi } \\
\text { Fernanda } \\
\end{array}$ & 75 & Tidak Tuntas \\
\hline 20 & Muhammad Aldi Dwi Kresna & 70 & Tidak Tuntas \\
\hline 21 & Muhammad Nuqoib & 85 & Tuntas \\
\hline 22 & Rafli Azril Kautsar & 70 & Tidak Tuntas \\
\hline 23 & Ramadhan Alfarizi & 70 & Tidak Tuntas \\
\hline 24 & Ridho Kusdiantoro & 80 & Tuntas \\
\hline 25 & Roy Evan Adnadya & 75 & Tidak Tuntas \\
\hline 26 & Tian Fajar Nugraha & 65 & Tidak Tuntas \\
\hline 27 & Vitho Perdana & 80 & Tuntas \\
\hline
\end{tabular}




\begin{tabular}{|c|l|c|c|}
28 & Yoga Aprilian & 70 & Tidak Tuntas \\
\hline 29 & Yusuf Lutfi Anabil & 85 & Tuntas \\
\hline \multirow{2}{*}{$\begin{array}{l}\text { Rata-rata } \\
\text { Nilai Tertinggi }\end{array}$} & 76,38 & \\
\cline { 2 - 3 } & Nilai Terendah & 90 & \\
\cline { 2 - 4 } & & 65 & \\
\hline
\end{tabular}

Berdasarkan tabel di atas diketahui bahwa nilai rata-rata hasil belajar siswa adalah 76,38. Nilai rata-rata secara keseluruhan sesuai dengan KKM pembelajaran PPKn yaitu 75. Meskipun demikian, secara klasikal jumlah siswa ayang tuntas belajar ada 18 siswa atau mencapai $62,07 \%$. Siswa yang hasil belajarnya belum tuntas ada 11 siswa atau sebesar $37,93 \%$.

c. Observasi

Pada tindakan siklus I ini, observasi dilakukan untuk mengetahui aktivitas siswa dalam pembelajaran kontekstual pada materi menampilkan sikap positif terhadap Pancasila sebagai ideologi terbuka. Observasi dilakukan untuk mengamati aktivitas siswa dalam kegiatan diskusi. Berdasarkan hasil observasi diperoleh data mengenai aktivitas belajar siswa sebagai berikut.

Tabel 4.4 Rekapitulasi Hasil Observasi Aktivitas Siswa Kelas XI Dalam Pembelajaran PPKn Pada Siklus I

\begin{tabular}{|c|c|c|c|}
\hline \multirow{2}{*}{ No } & \multirow{2}{*}{ Aspek Penilaian } & \multicolumn{2}{|c|}{ Jumlah Siswa } \\
\hline & & Aktif & Tidak Aktif \\
\hline 1 & $\begin{array}{l}\text { Siswa Aktif Bertanya dan Menjawab } \\
\text { Pertanyaan }\end{array}$ & 17 & 12 \\
\hline 2 & Siswa Aktif Bekerjasama & 20 & 9 \\
\hline 3 & Siswa Aktif Melaksanakan Tugas & 19 & 10 \\
\hline 4 & $\begin{array}{l}\text { Siswa aktif menyampaikan pendapat } \\
\text { mengenai pokok bahasan }\end{array}$ & 18 & 11 \\
\hline & Jumlah & 74 & 42 \\
\hline & Prosentase & $63,79 \%$ & $36,21 \%$ \\
\hline
\end{tabular}

Berdasarkan data di atas diketahui bahwa secara keseluruhan siswa yang aktif dalam pembelajaran kontekstual pada siklus I mencapai $63,79 \%$, sedangkan siswa yang tidak aktif dalam pembelajaran mencapai $36,21 \%$. Secara spesifik, dapat dijelaskan bahwa Siswa yang aktif bertanya dan menjawab pertanyaan ada 17 dan 12 siswa yang tidaka aktif. Untuk kategori siswa yang aktif bekerjasama ada 20 dan 9 yang tidak aktif. Sementara itu siswa yang aktif melaksanakan tugas ada 19 dan yang tidak aktif ada 10. Untuk kategori siswa aktif menyampaikan pendapat mengenai pokok bahasan ada 18 dan yang tidak aktif ada 11 .

d. Refleksi

Berdasarkan data yang diperoleh peneliti diketahui bahwa hasil belajar siswa mengalami peningkatan dari nilai rata-rata 72,07 meningkat menjadi 76,38. Meskipun demikian ketuntasan klasikal pada siklus I baru mencapai 62,07\% atau ada 18 siswa yang tuntas belajar. Demikian pula dengan aktivitas siswa dalam pembelajaran PPKn yang mengalami peningkatan dari 40,52\% menjadi $63,79 \%$ pada siklus I. Secara keseluruhan hasil belajar dan aktivitas belajar siswa mengalami peningkatan, namun hal tersebut belum 
sesuai dengan indicator keberhasilan yang ditetapkan peneliti yaitu ketuntasan klasikal menapai $80 \%$ dengan aktivitas belajar sebesar $85 \%$ siswa aktif dalam pembelajaran.

Berdasarkan refleksi tersebut, perlu adanya revisi dan improvisasi, sehingga kekurangan pada siklus sebelumnya tidak terulang pada siklus selanjutnya. Adapun beberapa bentuk revisi dan improvisasi tersebut antara lain:

1) Menjelaskan tentang penerapan kontekstual pada siswa.

2) Membiasakan siswa melakukan pengamatan dan mencari pemecahan masalah sesuai dengan pokok bahasan.

3) Memberikan motivasi dengan memberikan trik-trik berbicara di depan kelas sehingga tidak takut salah, malu, dan berani menyampaikan pendapat atau hasil diskusi.

4) Melatih siswa untuk tidak hanya memahami materi dengan baik tetapi juga menerapkannya dalam kehidupan sehari-hari.

5) Mempersiapkan segala sesuatu yang terkait dengan siklus II, sehingga kekurangan pada siklus I tidak terulang pada siklus berikutnya.

\section{Siklus II}

a. Perencanaan

Agar pelaksanaan pembelajaran kontekstual lebih maksimal maka pada perencanaan siklus II, peneliti menerapkan penerapan pembelajaran kontekstual dengan menggunakan metode yang sama yaitu dengan kegiatan pengamatan dan diskusi kelompok. Hal ini dilakukan karena materi pada siklus I masih berkaitan dengan siklus II ini. Tahap-tahap perencanaan yang dilakukan pada siklus II diantaranya:

1) Mempersiapkan materi pembelajaran

2) Mempersiapkan sumber belajar yang diperlukan

3) Mempersiapkan lembar kerja siswa

4) Mempersiapkan kelas dalam setting pembelajaran kontekstual dengan bantuan media pembelajaran

5) Membuat lembar observasi tentang aktivitas siwa selama proses belajar mengajar.

b. Pelaksanaan Tindakan Siklus II

1) Pertemuan 1

Pada pertemuan pertama ini guru mnejelaskan materi tentang menunjukan sikap positif terhadap nilai Pancasila. Untuk pertemuan kali ini, guru menggunakan media LCD. Melalui LCD, guru menjelaskan materi disertai dengan gambarf-gambar menarik terkait dengan sikap positif terhadap nilai Pancasila. Dangan adanya gambar tersebut diharapkan pemahaman siswa tentang materi menjadi lebih baik dan tentunya dapat dicontoh dan diterapkan dalam kehidupannya sehari-hari.

Pada pertemuan 1 ini, siswa belajar secara berkelompok untuk melakukan diskusi. Dalam kegiatan kelompok, guru memberikan kesempatan kepada siswa untuk melakukan pengamatan terkait dengan sikap positif terhadap nilai Pancasila yang dilakukan siswa di lingkungan sekolah. Kegiatan belajar dilanjutkan dengan pemberina tugas secara individual untuk mencari artikel atau gambar yang berkaitan dengan sikap positif terhadap nilai Pancasila yang dilakukan di luar sekolah.

Adanya berbagai rangkaian aktivitas dalam pembelajaran PPKn dengan model kontekstual, siswa diharapkan tidak hanya memhami materi dengan baik tetapi juga mengetahui implementasinya di lapangan kemudian nantinya termotivasi untuk menerapkannya dalam kehidupan mereka sehari-hari. Pembelajaran kontekstual memberikan suasana pembelajaran yang lebih menarik dan menyenangkan.

2) Pertemuan 2

Pada pertemuan kedua, siswa melaksanakan diskusi sesuai dengan kelompoknya. Siswa mendiskusikan tentang hasil pengamatan dan tugas individual yang dilakukan siswa di rumah tentang sikap positif terhadap nilai Pancasila. Aktivitas belajar selanjutnya adalah beberapa kelompok mempresentasikan hasil diskusinya dan kelompok lainnya menanggapi. 
Pada kegiatan akhir pembelajaran, siswa bersama guru menyimpulkan materi dan memberikan soal evaluasi. Berdasarkan evaluasi pembelajaran yang dilakukan oleh guru diperoleh data sebagai berikut.

Tabel 4.5 Rekapitulasi Hasil Belajar PPKn Siswa Kelas XI SMK Negeri 3 Semarang Siklus II

\begin{tabular}{|c|c|c|c|}
\hline No & Nama Siswa & Nilai & Keterangan \\
\hline 1 & Abdul Latif Agus Solikhin & 80 & Tuntas \\
\hline 2 & Adam Fajar Prasetya & 85 & Tuntas \\
\hline 3 & Adhika Muhammad Rizki & 80 & Tuntas \\
\hline 4 & Agil Lintang Tristiawan & 70 & Tidak Tuntas \\
\hline 5 & Agung Dwi Laksono & 90 & Tuntas \\
\hline 6 & Ahmad Arjuna Kurniawan & 75 & Tuntas \\
\hline 7 & Andre Pramuji Utama & 95 & Tuntas \\
\hline 8 & Aprialdo Budi Hendriawan & 75 & Tuntas \\
\hline 9 & Bachtiar Hanif & 80 & Tuntas \\
\hline 10 & Bagas Pramudita & 75 & Tuntas \\
\hline 11 & Djamaludin Akbar & 75 & Tuntas \\
\hline 12 & Edwin Mahendra & 85 & Tuntas \\
\hline 13 & Galang Awal Yanuar & 80 & Tuntas \\
\hline 14 & Harry Setiawan & 90 & Tuntas \\
\hline 15 & Heri & 80 & Tuntas \\
\hline 16 & Insan Al Faridzi & 85 & Tuntas \\
\hline 17 & Keavin Putra Purnama & 75 & Tuntas \\
\hline 18 & M. Hafis Arida Saputro & 90 & Tuntas \\
\hline 19 & $\begin{array}{l}\text { Mohammad Dafa Rizqi } \\
\text { Fernanda }\end{array}$ & 80 & Tuntas \\
\hline 20 & $\begin{array}{l}\text { Muhammad Aldi Dwi } \\
\text { Kresna }\end{array}$ & 75 & Tuntas \\
\hline 21 & Muhammad Nuqoib & 80 & Tuntas \\
\hline 22 & Rafli Azril Kautsar & 75 & Tuntas \\
\hline 23 & Ramadhan Alfarizi & 80 & Tuntas \\
\hline 24 & Ridho Kusdiantoro & 85 & Tuntas \\
\hline 25 & Roy Evan Adnadya & 80 & Tuntas \\
\hline 26 & Tian Fajar Nugraha & 70 & Tidak Tuntas \\
\hline 27 & Vitho Perdana & 85 & Tuntas \\
\hline 28 & Yoga Aprilian & 70 & Tuntas \\
\hline 29 & Yusuf Lutfi Anabil & 85 & Tuntas \\
\hline \multirow{3}{*}{\multicolumn{2}{|c|}{$\begin{array}{l}\text { Rata-rata } \\
\text { Nilai Tertinggi } \\
\text { Nilai Terendah }\end{array}$}} & 80.34 & \\
\hline & & 95 & \\
\hline & & 70 & \\
\hline
\end{tabular}


Berdasarkan data di atas dapat dinformasikan bahwa nilai rata-rata hasil belajar siswa adalah 80,34. Dengan perolehan nilai tertinggi 95 dan nilai terendah 70 . Secara keseluruhan ketuntasakan klasikal mencapai $93,10 \%$ atau ada 27 siswa yang nilainya tuntas. Sedangkan $6,90 \%$ sisanya atau ada 2 siswa yang nilainya belum tuntas.

c. Observasi

Pada kegiatan observasi ini, peneliti melaksanakan penialian terhadap aktivitas belajar siswa selama pembelajaran PPKn dengan menggunakan model pembelajaran kontekstual berlangsung. Berdasarkan hasil observasi, dapat disajikan data mengenai aktivitas belajar siswa berikut ini.

Tabel 4.6 Rekapitulasi Hasil Observasi Aktivitas Siswa Dalam Pembelajaran PPKn Pada Siklus II

\begin{tabular}{|c|c|c|c|}
\hline \multirow{2}{*}{ No } & \multirow{2}{*}{ Aspek Penilaian } & \multicolumn{2}{|c|}{ Jumlah Siswa } \\
\hline & & Aktif & Tidak Aktif \\
\hline 1 & $\begin{array}{l}\text { Siswa Aktif Bertanya dan Menjawab } \\
\text { Pertanyaan }\end{array}$ & 25 & 4 \\
\hline 2 & Siswa Aktif Bekerjasama & 27 & 2 \\
\hline 3 & Siswa Aktif Melaksanakan Tugas & 26 & 3 \\
\hline 4 & $\begin{array}{l}\text { Siswa aktif menyampaikan pendapat } \\
\text { mengenai pokok bahasan }\end{array}$ & 25 & 4 \\
\hline & Jumlah & 103 & 13 \\
\hline & Prosentase & $88.79 \%$ & $11.21 \%$ \\
\hline
\end{tabular}

Berdasarkan tabel di atas diketahui bahwa secara keseluruhan $88,79 \%$ siswa aktif dalam pembelajaran, sedangkan $11.21 \%$ siswa tidak aktif dalam pembelajaran. Secara kualitas dapat dijelaskan bahwa siswa yang aktif bertanya dan menjawab pertanyaan ada 25 dan 4 siswa tidak aktif dalam pembelajaran. Siswa yang aktif bekerjasama ada 27, dan 2 siswa tidak aktif. Untuk kategori aktif melaksanakan tugas ada 26 siswa yang aktif dan 3 siswa yang tidak aktif. Untuk kategori siswa yang menyampaikan pendapat mengenai pokok bahasan ada 25 dan yang tidak aktif ada 4 .

d. Refleksi

Berdasarkan data yang diperoleh peneliti, diketahui bahwa hasil belajar siswa mengalami peningkatan cukup signifikan. Hal tersebut dapat dilihat dari adanya peningkatan nilai rata-rata siswa dari 76,38 pada siklus I meningkat menjadi 80,34 pada siklus II dengan ketuntasan klasikal 93,10\% atau ada 27 siswa yang tuntas belajar.

Demikian pula dengan aktivitas siswa dalam pembelajaran PPKn yang mengalami peningkatan dari $63,79 \%$ pada siklus I meningkat menjadi $88,79 \%$ pada siklus II. Secara keseluruhan hasil belajar dan aktivitas belajar siswa mengalami peningkatan, dan telah sesuai dengan indicator keberhasilan yang ditetapkan peneliti yaitu dengan nilai rata-rata 75 dengan ketuntasan klasikal $80 \%$, serta aktivitas belajar siswa mencapai 85\%. Oleh karena itu, penelitian dapat dihentikan.

\section{B. Pembahasan}

\section{Siklus I}

Model pembelajaran kontektual (contextual teaching learning) merupakan konsep belajar yang membantu guru mengaitkan antara materi yang diajarkannya dengan situasi dunia nyata siswa dan mendorong siswa membuat hubungan antara pengetahuan yang memilikinya dengan penerapannya dalam kehidupan mereka sebagai anggota keluarga dan masyarakat. Dengan konsep itu, hasil pembelajaran diharapkan lebih bermakna bagi siswa. Proses 
pembelajaran berlangsung alamiah dalam bentuk kegiatan siswa bekerja dan mengalami, bukan transfer pengetahuan dari guru ke siswa.

Dengan penerapan model pembelajaran kontekstual, hasil belajar siswa mengalami peningkatan. Hal tersebut dapat dilihat pada diagram di bawah ini.

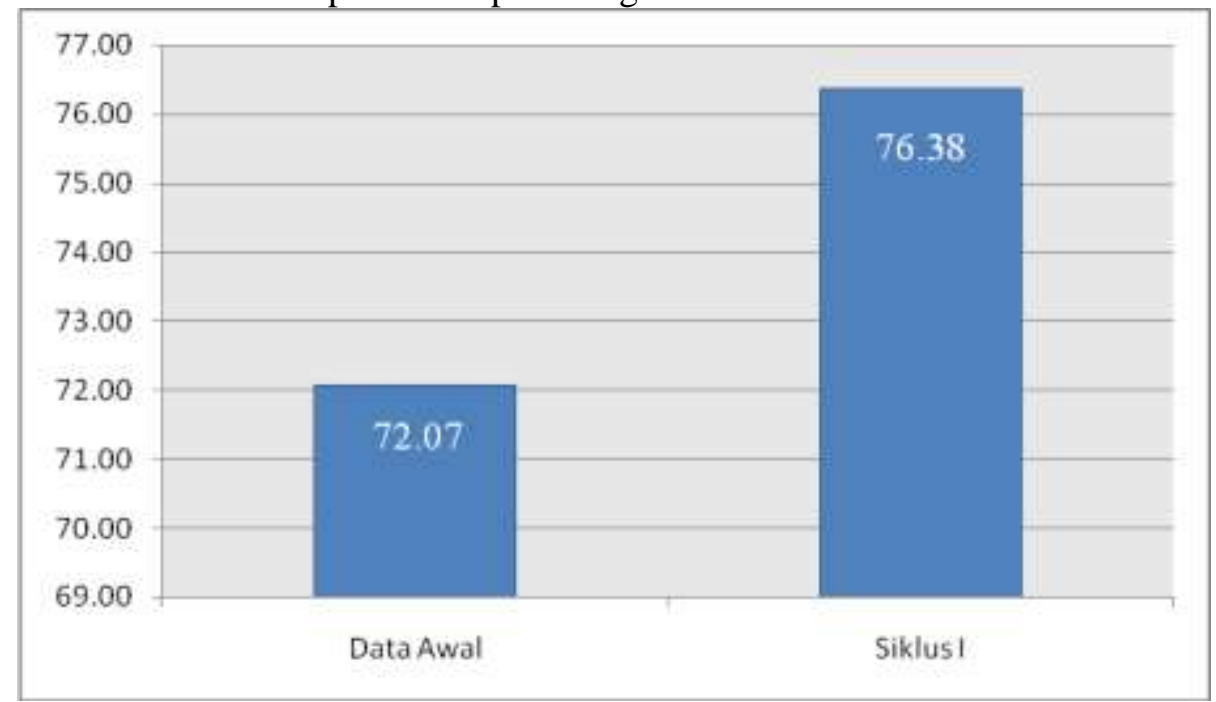

Gambar 4.1 Diagram Peningkatan Nilai Rata-rata Hasil Belajar Siswa Pada Siklus I

Diagram di atas menunjukkan adanya peningkatan hasil belajar siswa yang dapat dilihat dari nilai rata-rata yang diperoleh siswa dari data awal 72,07 meningkat menjadi 76,38 pada siklus I. Peningkatan nilai rata-rata hasil belajar siswa menunjukkan bahwa pemahaman siswa terhadap materi tentang menganalisis Pancasila sebagai sumber nilai mengalami peningkatan setelah guru menggunakan model pembelajaran kontekstual, dimana salah satu aktivitas belajar yang dilakukan adalah diskusi.

Peningkatan hasil belajar siswa juga dapat dilihat dari adanya peningkatan prosentase ketuntasan klasikal atau jumlah siswa yang nilainya tutas. Hal tersebut dapat dilihat pada diagram berikut ini.

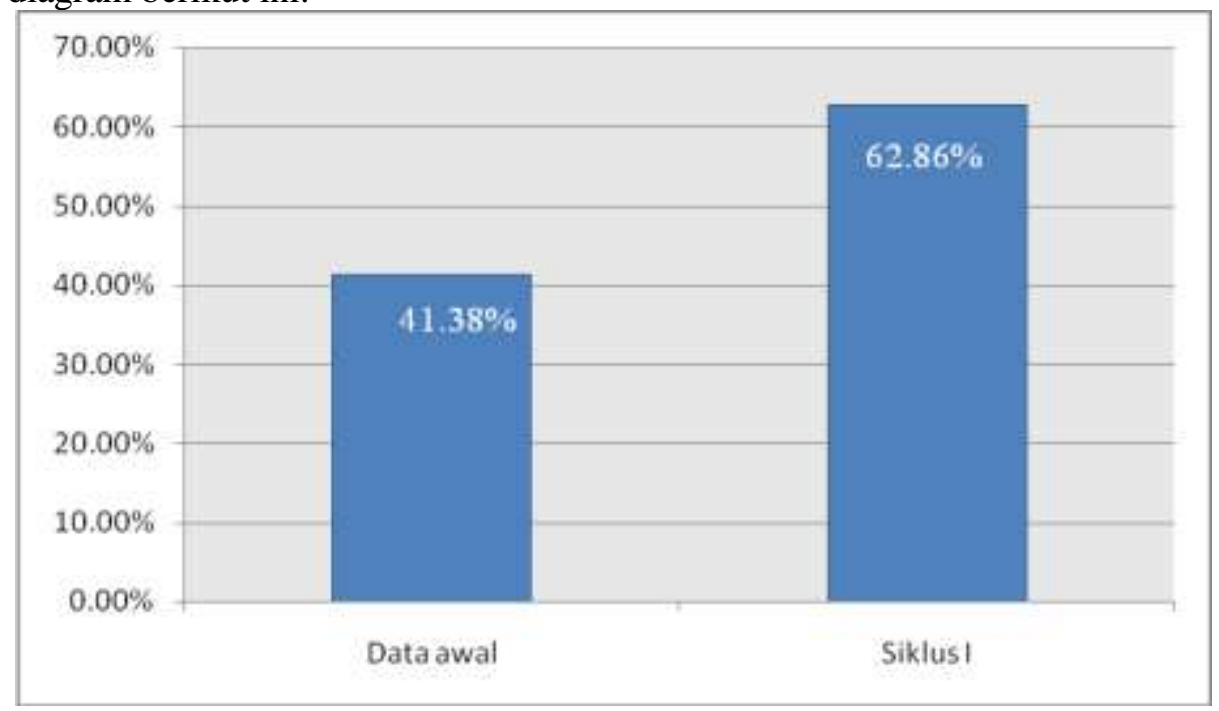

Gambar 4.2 Diagram Peningkatan Perkembangan Hasil Belajar Siswa Pada Siklus I

Berdasarkan diagram di atas diketahui bahwa penerapan model pembelajaran kontekstual dapat meningkatkan perkembangan hasil belajar siswa adari data awal ketuntasan klasikal siswa yang hanya mencapai $41,38 \%$ meningkat menjadi $62,86 \%$ pada siklus I. 
Peningkatan perkembangan hasil belajar ditunjukkan dengan banyaknya jumlah siswa yang nilainya tuntas yaitu dari data awal 12 siswa bertambah menjadi 18 siswa pada siklus I.

Peningkatan hasil belajar siswa dalam pembelajaran PPKn semakin lengkap dengan adanya peningkatan aktivitas siswa dalam pembelajaran. Peningkatan aktivitas belajar siswa tersebut dapat dilihat pada diagram berikut ini.

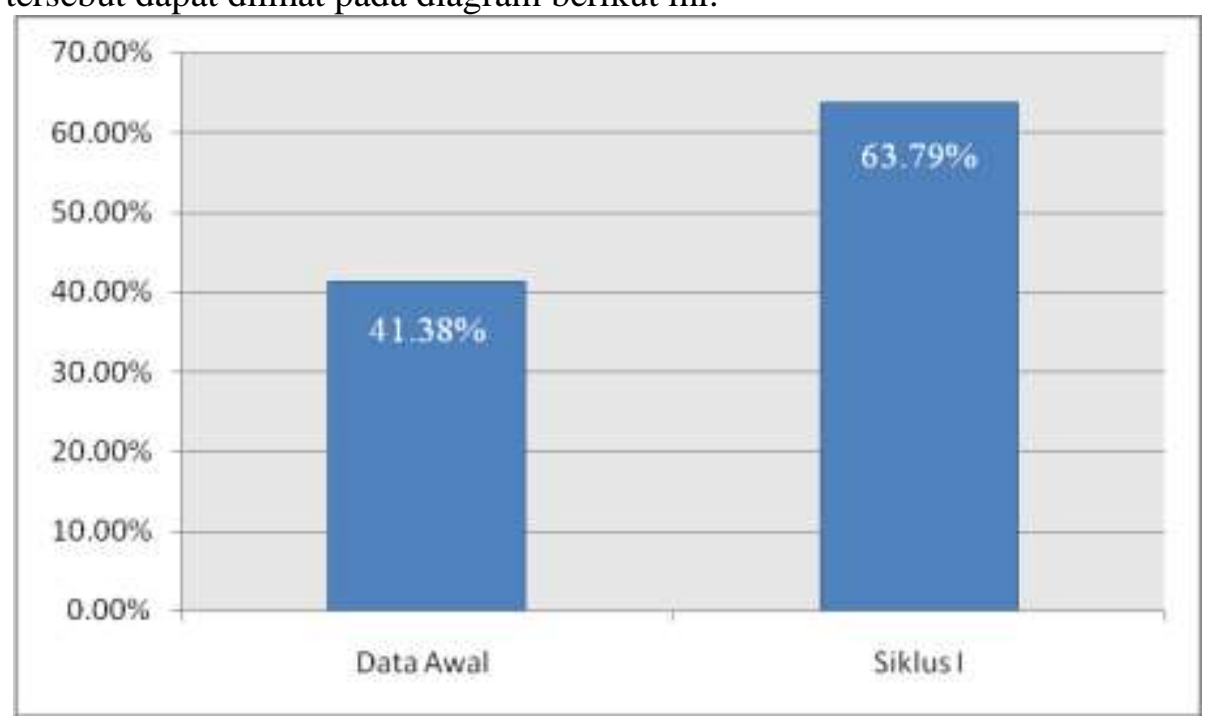

Gambar 4.3 Diagram Peningkatan Aktivitas Belajar Siswa Pada Siklus I

Diagram di atas memberikan gambaran adanya peningkatan aktivitas belajar siswa dari data awal $41,38 \%$ siswa yang aktif dalam pembelajaran meningkat menjadi $63,79 \%$ pada siklus I. Peningkatan aktivitas belajar ditunjukkan adanya peningkatan keberanian siswa dalam bertanya dan menjawab pertanyaan dan keaktifan siswa dalam menyampaikan pendapat mengenai pokok bahasan.

\section{Siklus II}

Pada siklus II, peneliti melakukan berbagai perbaikan dari tindakan yang dilakukan sebelumnya pada siklus I. Guru menggunakan LCD untuk menyampaikan materi dan juga memberikan petunjuk penggunaan LCD agar siswa nantinya dapat memanfaatkannya untuk melaksanakan presentasi pada saat diskusi kelas. Berdasarkan tindakan yang dilakukan pada siklus I diketahui adanya peningkatan nilai rata-rata haisl belajar siswa yang dapat dilihat pada diagram berikut ini.

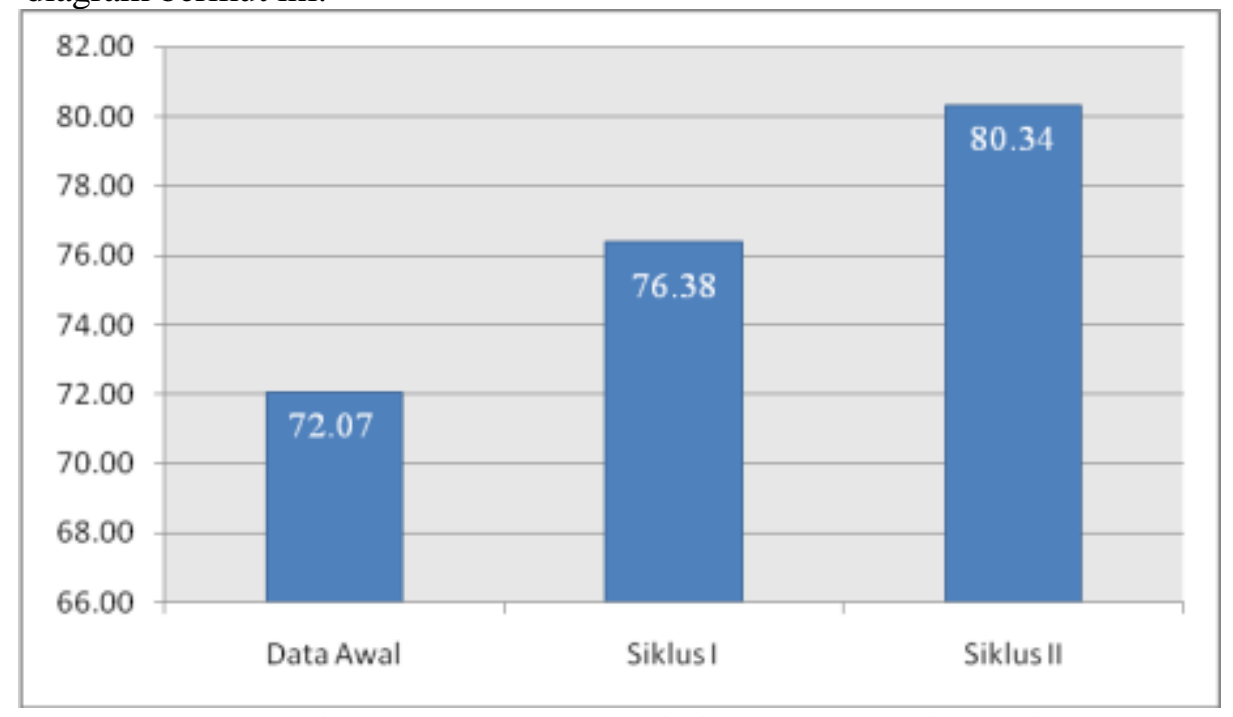

Gambar 4.4 Diagram Peningkatan Nilai Rata-rata Hasil Belajar Siswa Pada Siklus II 
Berdasarkan diagram di atas diketahui adanya peningkatan hasil belajar siswa yang dapat dilihat dari nilai rata-rata yang diperoleh siswa dari data awal 72,07 meningkat menjadi 76,38 pada siklus I dan meningkat kembali menjadi 80,34 pada siklus II. Peningkatan nilai rata-rata hasil belajar siswa menunjukkan bahwa pemahaman siswa tentang materi menunjukan sikap positif terhadap nilai Pancasila semakin baik.

Peningkatan juga terlihat dari perkembangan haisl belajar siswa yang tersaji dalam bagan di bawah ini.

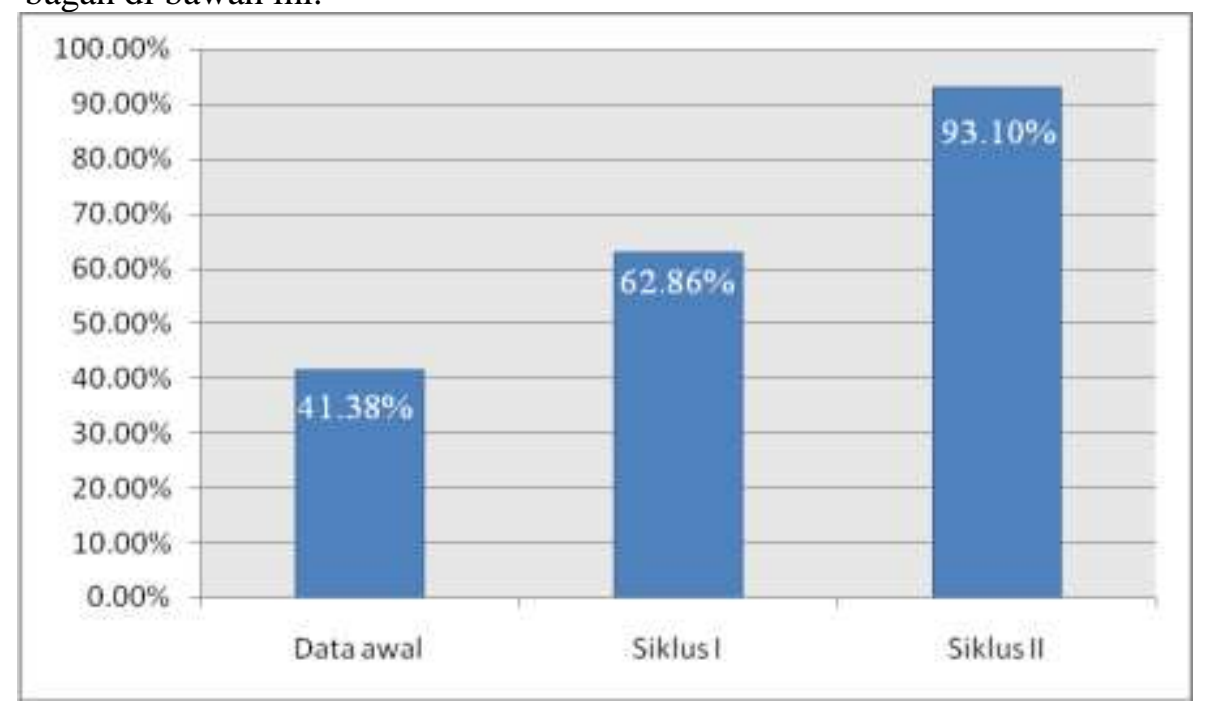

Gambar 4.5 Diagram Peningkatan Perkembangan Hasil Belajar Siswa Pada Siklus II

Diagram di atas menunjukkan adanya peningkatan cukup signifikan dalam perkembangan hasil belajar siswa kelas XI pada mata pelajaran PPKn dengan model kontekstual yaitu dari data awal ketuntasan klasikal siswa yang hanya mencapai 41,38\% meningkat menjadi $62,86 \%$ pada siklus I dan meningkat lagi menjadi $93,10 \%$ pada siklus II. Peningkatan perkembangan hasil belajar ditunjukkan dengan banyaknya jumlah siswa yang nilainya tuntas yaitu dari data awal 12 siswa bertambah menjadi 18 siswa pada siklus I dan menjadi 27 siswa pada siklus II.

Peningkatan hasil belajar siswa berbanding lurus dengan peningkatan aktivitas belajar siswa pada siklus II yang juga mengalami peningkatan yang cukup baik hingga mencapai $88,79 \%$ siswa yang aktif dalam pembelajaran. Hal tersbut secara lengkap dapat dilihat pada table berikut ini.

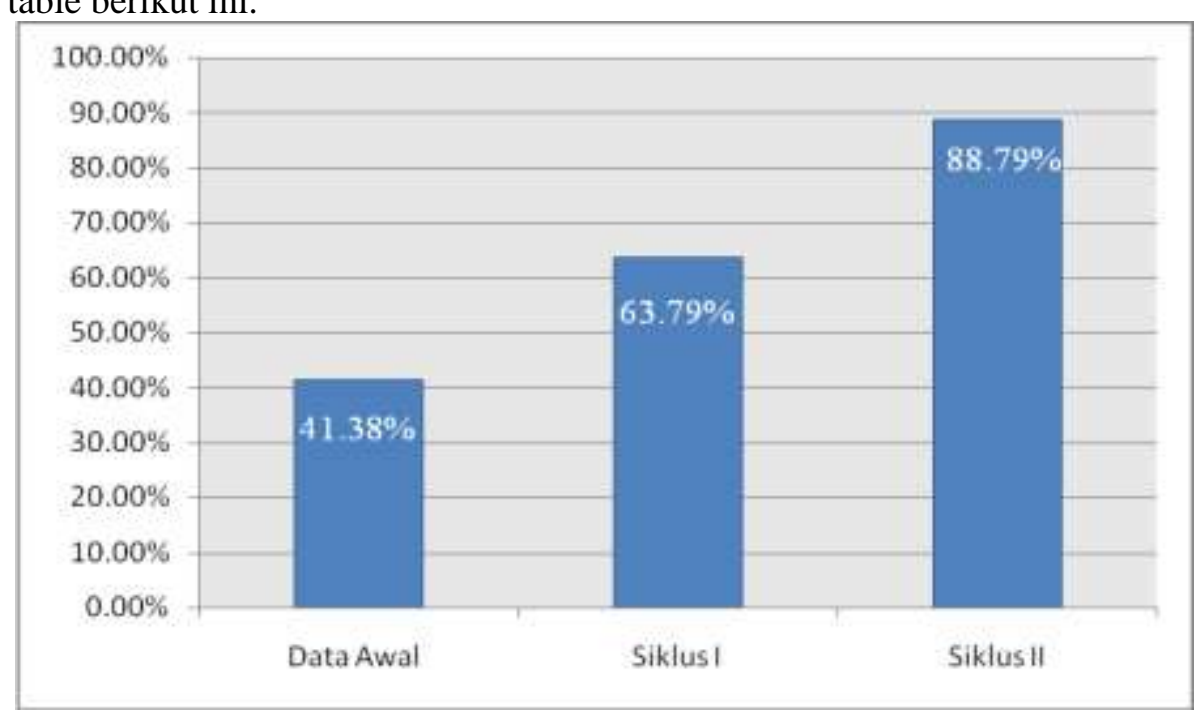

Gambar 4.6 Diagram Peningkatan Aktivitas Belajar Siswa Pada Siklus II 
Berdasarkan bagan di atas dapat duraikan bahwa aktivitas belajar siswa secara bertahap mengalami peningkatan yaitu darai data awal $41,38 \%$ siswa yang aktif dalam pembelajaran meningkat menjadi $63,79 \%$ pada siklus I dan meningkat kembali pada siklus II menjadi $88,79 \%$. Adanya jumlah siswa yang aktif dalam pembelajaran menunjukkan bahwa penggunaan model pembelajaran kontekstual dapat meningkatkan keaktifan siswa dalam pembelajaran PPKn.

\section{PENUTUP}

Berdasarkan hasil penelitian dan pembahasan terbukti secara ilmiah bahwa model pembelajaran kontekstual dapat meningkatkan hasil belajar PPKn pada siswa kelas XI. Hal tersebut dapat dilihat dari:

1. Adanya peningkatan hasil belajar siswa yang ditunjuukkan dengan adanya peningkatan nilai rata-rata dari data awal 72,07 meningkat menjadi 76,38 pada siklus I dan meningkat kembali menjadi 80,34 pada siklus II. Dangan ketuntasan dari 41,38\% meningkat menjadi 62,86\% pada siklus I dan mencapai $93,10 \%$ pada siklus II.

2. Adanya peningkatan aktivitas belajar siswa dari data awal $41,38 \%$ siswa yang aktif dalam pembelajaran meningkat menjadi $63,79 \%$ pada siklus I dan meningkat kembali pada siklus II menjadi $88,79 \%$.

\section{DAFTAR PUSTAKA}

Arikunto, Suharsimi. 2002. Prosedur Penelitian suatu Pendekatan dan Praktik. Jakarta: Rineka Cipta.

Depdiknas, 2002. Pendekatan Kontekstual (Contektual Teaching Learning (CTL). Jakarta: Depdiknas. Depdiknas. 2004. Model pengembangan Silabus Mata pelajaran dan Rencana Pelaksanaan Pembelajaran PPKn. Jakarta: Pusat Kurikulum, Balitbang Depdiknas.

Erwanto, Udin. 2007. Pendidikan Kewarganegaraan. STKIP PGRI.

Harsono. 2008. Model-Model Pengelolaan Perguruan Tinggi. Yogyakarta: Pustaka Pelajar.

Johnson, Elaine B. 2002. Contextual Teaching and Learning: What is is and why it's here to stay. United states of America: Corwin Press, Inc.

Miles, Mattew B dan Amichael Huberman. 2007. Analisis Data Kualitatif Buku Sumber tentang Metode-Metode Baru. Terjemahan Tjetjep Rohendi Rohidi. Jakarta: Universitas Indonesia.

Sanjaya, Wina. 2008. Strategi Pembelajaran Berorientasi Standar Proses Pendidikan. Jakarta: Prenada Media Group.

Slameto. 1998. Didaktik Metodik. Jakarta: Pustaka Jaya.

Sukarnyana, I.W. 1999. Penelitian Tindakan Kelas. Malang: Departemen Pendidikan Nasional Direktorat Jenderal Pendidikan Dasar dan Menengah.

Surakhmad, Winarno. 1994. Pengantar Interaksi Mengajar Belajar. Bandung: Tarsito.

Suryabrata, Sumadi. 1993. Psikologi Pendidikan. Jakarta: Raja Grafindo Persada.

Suyanto. 1997. Pengenalaan Penelitian Tindakan Kelas. Yogyakarta: IBRD.

Gie, The Liang. 2000. Kamus Psikologi. Jakarta: PN. Balai Pustaka.

Winkel, WS. 2001. Psikogi Pendidikan. Jakarta: Raja Grafindo Persada. 